\title{
Legal Education in the 21St Century and the Artificial InTELLigENCE
}

\author{
Ensino JuRÍDico no SÉCUlO XXI E A INTELIGÊNCIA \\ Artificial
}

\section{Educación Jurídica en el Siglo XXI E INTELIGENCIA Artificial}

Mateus de Oliveira Fornasier

1 Introduction. 2 Legal Education and Digital Technologies. 2.1 Skills Needed for a Scenario where Technology Becomes Ubiquous (Even in Law). 2.2 Interdisciplinarity for Lawyers understood as "Transition Engineers". 3 Artificial Intelligence in Higher Education. 3.1 Artificial Intelligence in Legal Education. 4 Concluding remarks. References.

\begin{abstract}
Objectives: We sought to study the main reflexes of the digital economy that influence legal education, and some of the operational suggestions that accompany criticisms of that process. To this end, some of the main suggestions made by experts in law and education to transform legal education in the face of the technological ubiquity scenario were observed. In a second moment, the transformations that higher education has been undergoing with the introduction of $\mathrm{AI}$ in the market and in universities were specifically analyzed. Finally, both the reflexes of AI in legal education and suggestions related to transformations that legal education must undergo were studied.
\end{abstract}

\footnotetext{
* Doctor of Law, Universidade do Vale do Rio dos Sinos (UNISINOS, Brazil, 2013). Post- Doctorate of Law, University of Westminster (United Kingdom, 2018-2019). Professor at the Stricto Sensu Postgraduate Program (LLM and PhD) in Law, Northwest Regional University of the State of Rio Grande do Sul. E-mail: <mateus.fornasier@gmail.com>. http://orcid.org/0000-0002-1617-4270
}

\section{(1)(3)}

R. Opin. Jur., Fortaleza, ano 19, n. 31, p.1-32, maio/ago. 2021 
Methodology: The hypothetical-deductive procedure method was used, with a qualitative and technical approach of bibliographic-documentary research, in this exploratory and interdisciplinary research.

Results: It was identified that legal education will have to move away from a retrospective epistemological stance, and evolve towards a prospective and projective stance, incorporating knowledge from technological areas and quantitative methodologies, without neglecting the exercise of traditional normative skills, communicative and narrative values that are highly evaluated by law professionals, thus emphasizing the need to foster student creativity. It is also concluded that higher education courses should incorporate coding in their curricula, in parallel with encouraging students' creativity and their communicative skills - however, a regulation should be developed in parallel, which must take into account the ethical risks of the use of AI in teaching. Finally, it is clear that the legal professions are not yet under a very pressing possibility of substitution by AI, but universities must make students aware that there are specific tasks in the legal professions that may be replaced by AI tools in order to advise them to focus on tasks that cannot be replaced by machines.

Keywords: Legal education. Digitization. Artificial intelligence.

\section{RESUMO}

Objetivo: Buscou-se estudar os principais reflexos da economia digital que influenciam a educação jurídica, e algumas das sugestões operacionais que acompanham as críticas a esse processo. Para isso, foram observadas algumas das principais sugestões realizadas por experts do Direito e da educação para se transformar a educação jurídica diante do cenário de ubiquidade tecnológica, primeiramente. Num segundo momento, foram analisadas, especificamente, as transformações que a educação superior vem sofrendo com a introdução da IA no mercado e nas universidades. Por fim, foram estudados tanto os reflexos da IA na educação jurídica quanto sugestões relacionadas a transformações pelas quais o ensino jurídico deve passar.

Metodologia: Utilizou-se o método de procedimento hipotético-dedutivo, com abordagem qualitativa e técnica de pesquisa bibliográfico-documental, nessa pesquisa de natureza exploratória e interdisciplinar.

Resultados: Identificou-se que o ensino jurídico terá de se afastar de uma postura epistemológica retrospectiva, e evoluir em direção a uma postura prospectiva e projetiva, incorporando conhecimentos de áreas tecnológicas e metodologias quantitativas, sem deixar de lado o exercício das tradicionais habilidades normativas, comunicativas e 
narrativas valorizadas nos profissionais do Direito, enfatizando-se, assim, a necessidade de fomento à criatividade do estudante. Também se conclui que os cursos superiores devem incorporar programação em seus currículos, em paralelo ao incentivo à criatividade dos estudantes e de suas capacidades comunicativas - porém, deve-se desenvolver, em paralelo, uma regulação do uso da IA que leve em consideração os riscos éticos de seu uso no ensino. Por fim, tem-se que as profissões jurídicas ainda não estão sob uma possibilidade muito premente de substituição por IA, mas as universidades devem conscientizar os estudantes que há tarefas específicas nas profissões jurídicas que podem vir a ser substituídas por ferramentas de IA, a fim de os aconselhem a se concentrar em tarefas não substituíveis por máquinas.

Palavras-chave: Educação jurídica. Digitalização. Inteligência artificial.

\section{RESUMEN}

Objetivo: Se buscó estudiar los principales reflejos de la economía digital que inciden en la educación jurídica, y algunas de las sugerencias operativas que acompañan a las críticas a este proceso. Para ello, se observaron algunas de las principales sugerencias realizadas por los expertos en derecho y educación para transformar la educación jurídica ante el escenario de ubicuidad tecnológica. En un segundo momento, se analizaron específicamente las transformaciones que ha venido experimentando la educación superior con la introducción de la IA en el mercado y en las universidades. Finalmente, se estudiaron tanto los reflejos de la IA en la educación jurídica como las sugerencias relacionadas con las transformaciones que debe atravesar la educación jurídica.

Metodología: Se utilizó el método de procedimiento hipotético-deductivo, con un enfoque cualitativo y técnico de investigación bibliográfico-documental, en una investigación de naturaleza exploratoria e interdisciplinaria.

Resultados: Se identificó que la educación jurídica deberá alejarse de una postura epistemológica retrospectiva, y evolucionar hacia una postura prospectiva y proyectiva, incorporando conocimientos de áreas tecnológicas y metodologías cuantitativas, sin descuidar el ejercicio de las competencias normativas tradicionales y de los valores comunicativos y narrativos valorados por los profesionales del derecho, enfatizando así la necesidad de fomentar la creatividad de los estudiantes. También se concluye que los cursos de educación superior deben incorporar la programación en sus planes de estudio, en paralelo con el fomento de la creatividad de los estudiantes y sus habilidades comunicativas; sin embargo, se debe desarrollar una regulación en paralelo que tenga en cuenta los riesgos éticos de la aplicación de IA en la enseñanza. Finalmente, está claro 
que las profesiones jurídicas aún no se encuentran bajo una posibilidad muy apremiante de sustitución por IA, pero las universidades deben concienciar a los estudiantes de que existen tareas específicas en las profesiones jurídicas que pueden ser sustituidas por herramientas de IA para poder aconsejarles que se concentren en tareas que la máquina no pueda reemplazar.

Palabras clave: Educación jurídica. Digitalización. Inteligencia artificial.

\section{INTRODUCTION}

The current context of legal education in Brazil shows a worrying picture, due to an extremely relevant factual contradiction. On the one hand, we have a scenario of increasing progression in the number of courses each year: between 1977 and 1995, 108 new Law courses were opened in Brazil, which means an average of six new courses per year; between 1995 and 2011, 55 new courses were created per year, totaling 1,121 Law courses at the end of this period; between 2011 and 2012, that number increased to 1,158 , which means 38 new Law courses created in a single year - and this expansion is much more pronounced in the private network than in the public one (FUNDAÇÃO GETÚLIO VARGAS, 2016, p. 27-47). On the other hand, not only the most recently reported economic crises, but also technological advances, have shown a trend of reduction of the size of the State's civil service in Brazil, an ever greater automation in the health sector services in general, and an increase in the presence of distance and telepresential courses.

NMC Horizon Report (BECKER et al., 2017) already predicted that the horizon for the use of AI systems in higher education would start approximately in 2022. According to the same report, currently AI has been regularly leveraged in higher education in the form of 24/7 online help desk - for example, the use of IBM Watson at Deakin University. There are possibilities for using more sophisticated virtual tutors and adaptive learning tools - which are often accompanied by concerns in the sense that technology cannot (and should not) replace human educators. In addition, machine learning already encourages progress in professional life and informal learning - as it is happening in the Smart Flower Recognition System project, a partnership between Microsoft Research Asia and the Chinese Academy of Sciences, to help botanists in China quickly identify plants with photos taken by smartphones. Through neural networks, the algorithms filter submissions of low quality images and identify the flowers in the photo database with more than $90 \%$ accuracy. To scale up AI possibilities over the next four to five years, higher education can start with open source 
programming and open software libraries for numerical computing, as provided by OpenAI and Google's TensorFlow.

But even with this very compromising scenario, there are perspectives from which the use of AI in education is considered quite promisingly. Hookway (2014), in Interfaces, for example, foresees a more balanced future for higher education, as he does not see AI as a tool, but as a third hemisphere of the brain that improves creative and cognitive learning processes - an equal and symbiotic partnership, or hybrid mind, between humans and their devices.

The change of scenery that society has undergone through the last decades emphasizes the relevance of researching legal education in the 21 st century, as we have shifted from a society configured by face-to-face interactions predominantly, with information recorded exclusively on physical substrates, with difficult accesses to information and very significant distances for communication, to a virtual society, with virtually short distances and greatly facilitated access to information. That description is obviously still quite incomplete, if we analyze all technological innovations in the most important important sectors of everyday life (economics, politics, industry, etc.), but it already serves as an illustration of innovative processes that take place in geometric progression, at very large steps, towards even greater social transformations. New production processes (3D printing and robotics), new ways of providing services (through automated assistants and artificial intelligence), increasingly new forms of communication (increasingly fast and reliable connections, internet of things), and even new ways to guarantee reliability in the most varied processes (new forms of cryptography, such as blockchain technology) enhance this situation, so Law as a whole - and legal education particularly - is already having its configuration affected. Traditional face-to-face teaching, in which teachers and students played roles in a hierarchical, vertical and dogmatic relationship (as it is based on previous knowledge applied to current and future problems) has been criticized not only by market experts, but also by Law academics themselves, and such criticisms, usually accompanied by wellfounded suggestions, cannot be left out in the process of reconfiguring the knowledge and teaching of Law.

The problem that guided this research can be described in the following question: what skills, knowledge and competencies does legal education have to offer to students in a scenario increasingly marked by digitalization, automation and revolution in ways of producing knowledge? As a hypothesis, it is presented that, in addition to a greater interdisciplinary knowledge of Law (encompassing its interfaces with technological and economic disciplines), the future Law professional will have to learn to exercise human capabilities, linked not only to previously developed sets of 
knowledge, but also, to communication, collaboration and creativity, in order to be able to use legal knowledge for the transformation of society and the market.

This article aims, in general, to study the main reflexes of the digital economy that have been influencing legal education, as well as some of the operational suggestions that accompany the criticisms of such process. To achieve that objective, this work was divided into three specific objectives, each one corresponding to a section of the development of this text. The first one seeks to observe some of the main suggestions made by Law and legal education experts from the most varied contexts (USA, Australia, Russia, among others) to transform legal education, especially with regard to the models to be followed for classes, curricula and skills/competences to be taught. The second section aims to analyze, in particular, the transformations through which higher education in general has been undergoing - and, in a prospective scenario, has the trend to suffer - with the introduction of AI in the market and in educational institutions. Finally, the third part focuses on the reflexes of the introduction of AI in Law and legal education in particular, as well as on the analysis of suggestions made in relation to transformations that legal education must undergo due to such an advent.

Methodologically, this research has an exploratory and interdisciplinar nature (combining Law, Education, Sociology and Technology knowledge), a hypotheticaldeductive procedure method, a qualitative approach (although it uses quantitative arguments sometimes) and a bibliographic-documentary research technique.

\section{LEGAL EDUCATION AND DIGITAL TECHNOLOGIES}

The current passion for technology (technophilia) in education has a profound impact on the classroom, changing the relationship between teacher and student and among colleagues, as such relationships have been increasingly based on the subjectmachine binomial, despite of the direct intersubjectivity, decreasing thus the ability to form bonds, the level of connection between teacher and students, and among students as well (GUILHERME, 2019, p. 47). In parallel, new learning processes are being developed, with teachers becoming facilitators of the process, and no longer the holders of specialized knowledge to be taught.

Legal education has tended to be "retrospective" hitherto, based on the transmission of established knowledge - analysis of existing acts, regulations and cases, etc. -, which gives the impression that the examination and understanding of historical developments enables the resolution of future problems through the application of previous doctrines and legal decisions. The educator-student relationship was, therefore, necessarily hierarchical. But past experience, held by a teacher with knowledge and 
authority, may not be relevant in a changing reality, when all information is easily available online. Thus, education needs to become much more forward-looking and based on skills, not on content (FENWICK; KAAL; VERMEULEN, 2020, p. 107).

The massive production and availability of digital information has led to wideranging technical and social changes, which present new methodological challenges to legal studies (ALTWICKER, 2019, p. 245). Obtaining legally relevant information by digital means, such as Court decisions, State rules, contracts, doctrinal and scientific texts, research, legal facts and their metadata, such as number of words and inter and hypertextual connections, triggers the pluralization of methods, and the traditional ("analogical") hermeneutics of Law will increasingly have to accommodate knowledge from data analysis (which is becoming more and more "digital"). Then, hermeneutics will become increasingly intertwined to quantitative methods, methodologically based on Statistics, Econometrics and Sociology, among others, and the elaboration of new theories that better match the ontologies to deontology will be essential to overcome difficulties that emerge for legal theory.

Digitization of Law, which means the dissemination of legal data and automation of legally relevant information collection, makes additional forms of legal knowledge available, as it changes the ways of representing that knowledge. Data-powered discoveries about Law, obtained through quantitative approaches, are no longer incorporated only in "legal statements", but, on the contrary, they are extended to graphical representations and quantitative models, resulting from quantitative analyzes about Law which can be represented in histograms, tree diagrams, scatter plots and word clouds, for example (ALTWICKER, 2019, p. 225).

Legal data processing also implies changes in the traditional functions of legal knowledge - which is basically the systematization and generalization of regulatory structures for the purposes of knowledge production and as a reservoir of regulatory options, as well as the preparation and criticism of decisions and laws, ensuring legal teaching and learning (ALTWICKER, 2019, p. 226). Legal data analysis adds at least two functions to legal knowledge: it allows a certain predictability of a specific result for legal decisions, which could increase legal transparency and consistency in Courts' decisions, in addition to preventing human rights violations by States, for example; and demonstrates the efficiency of regulations or legal regimes, which could be interesting, for example, to better understand the conditions of general conformity with norms. Legal knowledge acquired this way can then be used to improve decision-making and law-making.

A synergy between traditional legal rationality, which makes legal rationality visible and applied, and data-driven approaches, must be achieved, and this could increase the reliability of Law, but without forgetting the need for critical ordering of 
that process. Empirical quantitative legal studies, in this sense, could become one more basis on which doctrinal arguments can be formed or criticized, alongside historical or ethical arguments, for example.

Legal education must undergo a process of transition from traditional knowledge acquisition to a systemically different one, built on the basis of information technologies. Measures taken for the computerization of education must aim at training students, in manners that enable them to work effectively in new economic conditions. For a future lawyer, it is important to obtain not only a certain amount of theoretical knowledge, but also practical skills, and digital processes contribute to that. But specific electronic formats require development. The proven methods of portfolio, distance learning, intermediate and final tests of various types, must be preserved, but they need several innovations: digital models of various forensic situations, and digital descriptions of legal cases, digital databases - such as material analysis of fingerprints, legal acts and procedural documents, etc.), digital video archives of various types of legally relevant information (including those of a regulatory and statistical nature), digital experience and digital opinions of experts in various legal matters, and those are simply some examples of means and tools to be incorporated not only in legal education, but also in the repertoire of skills with which professionals will work (YAVORSKIY; MILOVA; BOLGOVA, 2020, p. 461).

Law school graduates must be able to safely qualify a specific legal situation, receiving the necessary information from several kinds of sources, which means developing a good command of skills related to digital technology. They need to acquire knowledge about the creation and circulation of electronic documents such as petitions, as well as to interact with individuals and entities through information and telecommunications technologies (MIRONOVA; BOGDANOVA; SIMONOVA, 2019, p. 5). At the same time, legal and technical protection against information distortion must be considered - which leads, for example, to the introduction of big data in everyday legal practice, which will significantly reduce the importance of document examination. With the use of such technological systems, the use of illegal information will become increasingly difficult, and it makes the work of a lawyer simpler, because one will have to deal each day less with dishonest opponents, for example. Future lawyers need to be educated and trained not only in the classic knowledge and skills, but also in the use of the most varied technical means - which will allow the most complete dissemination of information on the studied topics, in addition to helping to make classes become more practical. 


\subsection{SKILLS NEEDED FOR A SCENARIO WHERE TECHNOLOGY BECOMES UBIQUOUS (EVEN IN LAW)}

It is interesting to carry out comparative studies, verifying what has been debated in other countries about changes in legal education, so that such information can be compared to Brazilian needs and reality. In Australia, for example, the leadership in the quest to understand technological evolution and formulate responses was taken by the Law Society of New South Wales and its report on the Future of Law and Innovation in the Profession (FLIP), in which that organization recognized seven essential skills/areas of knowledge to the success of future Law practice from two main interrelated streams of knowledge - the ability of understanding and employing technology - and a list of skills that result in a "ready-to-practice" graduate (THE LAW SOCIETY OF NEW SOUTH WALES, 2017, p. 78-79):

a) practice skills (interpersonal and professional): interpersonal skills (i.e. collaborative work) are currently obtained in clinics and extracurricular activities; professional skills (writing, interviewing, presentation, advocacy/negotiation, etc.) are taught in the practice internships. But these skills should start to be distributed among the various moments of legal education, in order to build and reinforce the initial moments of learning without unnecessary repetition;

b) business skills: Business skills are necessary for almost every area of legal practice, whether a business or employment with companies, government or nonprofits. They are taught, to some extent, in internships and, in Australia, they seem to be seen as part of external legal education. At the university level, this results from the ubiquity of business training available as part of a double degree or before Law studies, if it happens in the students' interest;

c) project Management: although legal work in the form of dispute resolution or drafting contracts are forms of projects that require management, these skills do not appear to be subject to any formal legal education. Thus, it is recommended that students should be asked to develop project management skills as part of extracurricular activities (i.e. editing legal journals);

d) internationalization and Cross-Border Practice of Law: International Law subject has been integrated to the curricula of many Law schools. Further research should thus be conducted on the need for courses focused on cross-border legal practice (i.e. cross-border transactions and disputes), and on the appropriate internship for these courses;

e) interdisciplinary experience (interaction with clients and professionals from other areas): the contact of students with other areas of knowledge usually results 
from other kinds of training, generally external to the course. Exposure to clients, on the other hand, occurs through clinics, or volunteer work, internships and jobs;

f) resilience (flexibility and ability to adapt to changes): the frequency and degree of change to which the legal professions are exposed suggests that students and legal professionals can benefit from education that deals with change management and development resilience.

Regarding the use of technological tools, innovative developments in the elective disciplines of Law course (i.e. courses on application development) and extracurricular activities, such as competitions, are recommended. In addition, it is necessary to consider which aspects of technology need to be included in the main courses blockchain in contracts and properties, electronic discovery in civil proceedings, etc. and whether new subjects, such as programming for lawyers, are necessary. Maybe all lawyers need a certain baseline of technological aptitude, but otherwise it will be a matter of personal preference related to the acquired technological skills.

Human legal workers will continue to exist, but they must adapt their skills to the constantly changing world (LEGG, 2018). Technological advances can define a lawyer and change his/her features, and clients may soon have access to personalized legal advice and documentation without the need for a lawyer. Digital technologies do not seem to be giving much time for more immediate and efficient forms of conflict resolution to emerge. Maybe disputes regarding automobile accidents will be very soon resolved with checks on the records and programming of the automated vehicle; consumer complaints about delivery services may be quickly solved through GPS verification; maybe divorce procedures will take place from the moment that someone's smartphone detects, through GPS and text messages, that someone in the couple was unfaithful; and maybe last wills and testaments will be executed as soon as a wearable device detects the death of its user (KOEBLER, 2017).

An alternative view of this situation is that only human lawyers can practice Law (LEGG, 2018), something that could be concluded from three perspectives:

a) a human lawyer is necessary to protect clients from unqualified and unethical devices, thereby promoting competence and integrity in the public interest. The lawyer-client relationship is not merely commercial or consumerist, but fiduciary - unlike relationships with a taxi driver, a travel agent, or a real estate agent, which were shaken by Uber, Expedia and AirBnB;

b) legal practice requires a lawyer to provide the client judgment, discretion, creativity, empathy and understanding - characteristics that are very human, and perhaps impossible to be entirely acquired soon by algorithms; 
c) lawyers, in their many roles, are essential to maintain civil society, freedom and the Rule of Law - values, goals or conditions that humans seek to protect.

However, each one of those reasons may be insufficient to contain the evolutionary march of technology. If legal services are not accessible or appreciated for the value they offer, consumers will choose legal services provided by technology, even if it has inferior quality - although, in fact, in many cases, technology can even be as good as or better than that of the human lawyers. The current puzzle faced by legal education and practice is captured by aphorisms such as "time will tell" and "time waits for no one”, then. Breaks are clearly underway, but the result is unknown. Thus, new legal operators (lawyers, mainly) need to be equipped with the necessary skills to fulfill their calling in this constantly changing environment.

Webb (2019, p. 72) inquires about the ways through which Law courses' curricula should be designed when the Law-technology relationship is understood as a critical part of a continuous and profound transformation on what it means to be a lawyer and a human being. Considering that information technology is no longer a collateral novelty, but one of the factors that most influences socialization, jurists can no longer resist to it. Thus, focusing on a few simple changes - with only a few new skills being introduced in the legal curriculum, for example - would constitute a significant error of purpose, since the complex intertwining between human and technology in conditions of hyperconnectivity must be taken seriously. Consequently, just as information technology cannot be separated from other facets of what it means to be a human being, technology must also be at the core of the processes of thinking about legal education. Thus, five principles should be observed as a starting point for the discussion about the development of totally new curricula (WEBB, 2019, p. 20-24):

a) pervasivity: the real problem that should emerge when one thinks about Law and technology is the connection and the difference between both terms. Law must be understood as a technological form - for the resolution of conflicts and establishment of models of conduct -, and technology, as a form of Law, for it establishes rules that must be followed in order to achieve certain goals;

b) interdisciplinarity: the most pressing social problems do not fit into conventional academic disciplines, as they are complex, normative, fluid, trans-scientific and trans-legal - so, they cannot be solely solved by Law, science or technology. The importance of the ability of lawyers to work in an interdisciplinary and collaborative way with other areas is already professionally and academically recognized, but that ability seems to be poorly translated for the student. With the increasing fluidity of knowledge and professional functions, the need for interdisciplinarity is the most pressing 
one, maybe. In this sense, working along a variety of disciplines is fundamental to deal with the phenomenon of Law as an adequate field of investigation, and not as an epistemologically isolated discipline. It is essential for legal professions to become increasingly similar to other professional branches (i.e. business management, design, and medicine), in which social and computer scientists, ethics specialists, economists, organization theorists, among others, would have much to teach and collaborate in building theories and solving practical problems;

c) reflection on design: the crisis of several legal institutions today, such as access to justice, and the timing of lawsuits' processing, is a problem both of resources using and structural legal design. Thinking about Law as a design problem includes criticizing the role of legal technology. Technology in general has been presented as a design solution, and there is undoubtedly a lot of effort in using technology to solve real-world problems. But much of that work is being used to produce localized fixes for very specific problems. One should also reflect on the systemic consequences of the reconstruction of Law around disparate and often disconnected technological solutions. Agile, problem-oriented and tool-driven design is welcome, but it should not replace larger policy approaches to institutional design and rules. Legal courses should play a central role in initiating and shaping those topics, which go beyond events by Law programmers and applications. Legal design laboratories may present a good institutional model, facilitating designoriented teaching and research, although they may be limited if they focus very narrowly on the design of technology and tools as their main modus operandi. ${ }^{1}$

d) ethics and Governance: ethics can be considered a key and unifying aspect of the branches of knowledge that are intertwined to shape a technological future in which well-being will be increasingly dependent on ICTs. Perhaps the main ethical challenge is intrinsic to the nature of the technology itself mainly its tendency to seek greater flexibility and efficiency on its own. In a hyperconnected world, individuals not only use technology, they are also being used by it. This has significant implications for what it means to be human and a legal person. The obnubilation of the subject-object relationship between humans and technology under conditions of hyperconnectivity is an inevitable characteristic of life, and the obsolescence,

\footnotetext{
${ }^{1}$ For a deeper discussion on the importante of design of technological Solutions for Law, see the text by Hagan (2020), Design comes to the Law School.
} 
in the face of technology, of various notions that underlie the meaning of the human, is irreversible. A critical issue for governance, therefore, is the way in which human reification is addressed and/or managed in the emerging and post-human information age. Thus, Law courses should reflect on the ways through which lawyers contribute to the construction of the republican and participatory subject, even in the face of such great challenges - in order, thus, to become professionals capable of providing unique and typical legal responses. The skills to recognize and engage in policy debates, as well as to properly advise on a variety of Law and governance solutions will also be important for the future legal professional, then.

e) skills are not (yet) easy: although the focus on training in a hyperconnected environment is reinforced, this should not replace the development of essential critical thinking skills and creative problem solving. Such capabilities can be even more critical for legal work, as automation constantly reduces the need for a deep human knowledge of Law as it is currently known.

Bennett-Moses's (2019) proposal for legal education - not only in the sense of training for the professional future, but rather, as the development of citizenship in an automated and digital world - goes through several pragmatic changes. For example, updating legal curricula should absorb disciplines in statistics and modeling to take into account more recent examples of data processing. In addition to basic statistics, students should be taught about the different ways through which data can be analyzed and used to draw inferences or make predictions.

\subsection{INTERDISCIPLINARITY FOR LAWYERS UNDERSTOOD AS “TRANSITION ENGINEERS"}

In addition to adjustments to course content, broad, interdisciplinary thinking based on problems in important contemporary issues should have a place in education - for example, ethical considerations for data-based inferences and decision-making in Court sentences, policing, assessment of policy proposals to manage climate change, etc. This would encourage students to understand how knowledge from many different disciplines feed themselves back and combine to address important contemporary problems. It is worth remembering that AI as it is currently being developed is efficient for single tasks such as equation solving, but it is still very ineffective in tasks that require creativity. As creativity and interdisciplinary skills will continue to be human domains for longer than expected, they constitute the basis for interesting training for the human professionals of the future. 
Historically, lawyers have been more important when they operate as "transaction engineers", who create opportunities for new forms of business and other social relationships (FENWICK; KAAL; VERMEULEN, 2020, p. 107-108). Lawyers design innovative contracts, which protect high-risk investors, by intermediating the relationship between investors and innovative ventures created by inexperienced entrepreneurs - and in a scenario of disruptive technologies developed by startups, those activities are very important. In addition, the work lawyers do in establishing agreements, partnerships and conflict resolution has also been an important classification device for entrepreneurs who need more than just investors to start and scale their businesses. And contractual mechanisms, as well as the reputation-dominated market for lawyers, reduce information asymmetries between entrepreneurs and investors - which are necessary to bring together the demand and supply side of venture capital in an effective and mutually advantageous way.

The performance of the "transaction engineer" role that lawyers can play will require knowledge of coding - mainly due to the growing importance of information technologies in legal practice (FENWICK; KAAL; VERMEULEN, 2020, p. 110). Legal Tech - platforms, databases, software, applications and IT services to assist lawyers, which may even involve AI and blockchain technology - is changing the way Law is practiced. The success of such technologies, as well as of the start-ups that develop them, will very soon replace much of the work of trainees and beginning lawyers - such as proofreading, writing, etc. - as those autonomous services do not suffer from human flaws when performing repetitive tasks. Legal Tech can quickly transform Law offices and departments into virtual offices - platforms with an emphasis on connecting legal and other professionals in a collaborative online environment, involving human actors and machines. When successful, the platform model will create a flexible and accessible community of professionals with different skills and experience. The larger the community, the easier it is to offer customized solutions for customers' needs.

The development of digital technologies transforms practices for which lawyers are trained (ERSHOVA et al., 2019, p. 148). For example, legislative activity has long been focused on the preparation of regulatory legal acts. But the introduction of new financial technologies - cryptocurrencies and blockchain, AI, virtual commerce and robotic consulting - has required the development of new regulatory models that include non-traditional stages that are completely different from legislation. And the development of financial technologies and services has demonstrated the impossibility of traditional legal regulation to create their legal regulatory base. Thus, what should be thought of, in terms of conduct regulation, is the development of applied structure solutions, which provide for a rapid implementation of innovative technologies and 
services. Therefore, the competencies established by State standards for legal education must be carried out on the basis of digitization.

A much better technical understanding of the main technologies involving computers, communication networks and AI will be needed not only for legal education. Coding and data analysis seem like a good starting point, but other important subject-specific skills and abilities are also needed in a changing world. Therefore, the development of skills that lead to better decision making in conditions of cognitive and normative uncertainty must take place. Three skills which distinguish legal thinking and are relevant to digital transformation can be described as it follows (FENWICK; KAAL; VERMEULEN, 2020, p. 114):

a) complex problem solving: legal thinking deals with creative problem solving, involving complex facts through criticism, analysis and application - which are useful skills for future challenges;

b) incentive-based thinking: legal rationality involves studying the impact of norms on human behavior. Incentive-based thinking can be powerful in the digital age, in which traditional systems, models and assumptions will be revised, and thinking about the effects of technological architecture on human behavior will be crucial for the best architecture;

c) narrative and persuasion: due to the frequent plurality of possible answers to legal problems, a convincing narrative is important for the knowledge of the decision maker's opinion. This matches the needs of a digital world in which the best solution is not totally visible.

Thomson's (2020) understanding of legal education in times of disruption caused by technological advances is that, at first, changes have more to do with ways of assisting the work of Law operators (tools, applications, new forms of communication, intelligent assistants, etc.) - being that the types of work to be carried out are affected, but not its essence. That is, legal education will need to adapt to those changes, but the primary skills taught by the Law school will still be useful and necessary in a legal world complexed by ICTs and assisted by AI. In fact, AI applications are already promoting a wide range of legal, economic and social implications (DIAMOND et al., 2018). As AI offers opportunities to reduce or eliminate routine and time-consuming tasks with ediscovery, contract review and other traditional attorney roles, the most innovative Law operators adapt to take advantage of new opportunities. Improving the prediction of legal outcomes is an example of leveraging $\mathrm{AI}$ in the legal profession to better understand data.

Big data, AI, e-discovery tools, document automation, communication and collaboration tools, and cloud-based case management systems constitute only a sample of the ways in which technology is transforming legal practice in the 21st century 
(DIAMOND et al., 2018, p. 23). That situation illustrates the fact that thirty-one states out of the fifty that form the USA, in 2018, already demanded from their lawyers to understand the risks and benefits of technology (Comment 8 of Rule 1.1 of the Model Rules of Professional Conduct of the American Bar Association, ABA). The State of Florida, for example, has added a requirement for continuing legal education for technology.

Best advocacy practices in the social media age include informing clients about the responsible use of social media when representing and developing comprehensive social media policies. Lawyers must already deal with the use of social media in a variety of contexts, including the multiparty court, and they will have to change their traditional advocacy structure to include social media from the initial entry of clients to the completion of a case. After the admission of each case, lawyers must provide careful client advice on social media in the digital age. This includes recommendations on not publishing information and opinions related to pending litigation on social media for example, and this is reflected in legal education, which should include, both in undergraduate and refresher courses in Law, for example, advice on postures in social media.

Leskova, Serova and Lukyanova (2019), when analyzing the main trends in approaches to economic and legal education in the context of the digitalization of society, point to the need for new competences and skills to be also needed in Master of Laws (LLM, or Latin Legum Magister) programs, which allow the identification specialized training fields, connecting practice requirements and educational standards for the correction of educational programs, considering the professional tasks that will be required in the future. To carry out their work, the authors comparatively analyzed training programs for managers and lawyers at universities inside and outside Russia, and concluded that, in the context of the digital economy, LLM must offer knowledge in the field of modern information technology, interdisciplinary tools for solving professional tasks, comprehensive thinking skills and analytical skills. And the implementation of such innovations require the creation of stable collaborations both within the university and with representatives of the IT sector and the main companies that foresee the implementation of digital technologies.

The development of the digital economy, therefore, makes pressure on LLMs to also include the study of peculiarities of the action of neural networks and distributed registration technologies, prediction of the legal consequences of the introduction of control mechanisms in relation to cryptocurrencies, etc. (LESKOVA; SEROVA; LUKYANOVA, 2019, p. 843). And successfully achieving the formation of new skills for masters, which guarantee their participation as professionals in digital markets, is something that demands the integration of applied elements of these phenomena in 
educational programs. This problem can be solved by establishing a closer interaction between universities and business involved in the digital sector of the economy, such as the participation of students in projects associated with the cases of real companies and digital markets.

\section{ARTIFICIAL INTELLIGENCE IN HIGHER EDUCATION}

Despite the changes and reforms brought to the classroom and teaching methods due to the evolution in hardware, software and online services, the real revolution in education is yet to come, due to the use of AI (SUBRAHMANYAM; SWATHI, 2018). With AI, expert systems can be designed to interact with the world in ways such as visual perception, speech recognition and intelligent behavior, many of which were considered essentially human capabilities hitherto. AI would be very efficient in education, for example, in creating data collection algorithms to provide detailed and personalized feedback from students, which could make possible interpreting a student's needs and designing an appropriate assessment. AI systems can show student abilities, repeat lessons and design personalized learning plans for each student. AI would thus enable powerful virtual teaching assistants.

Fast developments in information technology, such as deep learning, big data and neural networks, demonstrate the arrival of AI. With it, the thinking, emotion and social skills that were previously considered unique to the human are gradually being carried out by AI, and education/teaching based on these skills tend to cause profound changes. For Zhao and Liu (2019, p. 47), facing educational changes in the AI era is both a challenge and an opportunity for educators in general.

AI will inevitably move education towards learning wisdom. The great goal of human use of $\mathrm{AI}$ is to free mankind from basic and repetitive work, to make possible to get involved in more important or more interesting things. But education is basically divided into two aspects: "teaching", which is the transfer of knowledge, and part of the educator's work that AI can perform better than the human; and "education", which is the cultivation of character, the incentive for students to explore the unknown, in discovery, in creation, and in the love of knowledge - and this part is difficult to substitute for AI (ZHAO; LIU, 2019, p. 50). Teachers, lecturers and professors, therefore, must constantly update their teaching wisdom, reflect and summarizing experiences, and make full use of the latest sciences and technologies in the cultivation of talents.

Timms (2016, p. 701) proposes that the field of applied AI to education (AIED) is already mature enough to involve students in new ways of learning and teaching, and to help teachers teach more efficiently. The intelligent systems developed to date within 
the framework of AIED used computers and other devices that were not specific for education, but future technologies, designed specifically for learning and teaching, combining the power of AIED with robotics and sensors for monitoring environments and behaviors (i.e. internet of things, or IoT) will enable AIED for full use in classrooms. The author believes that physical schools will still exist in the coming decades to some extent, and teachers will continue to promote learning among students - but there will be cobots, teachers' assistants in classrooms (a technology that, perhaps, will not be available in a few years, but that should start to be developed from now on). It also provides intelligent classrooms, with support sensors, with AIED applications built into them.

The exploration of new possibilities of interfaces between students, teachers and assistive technologies, parallel to the investigation of the application of IoT in education, as well as robotics shaping knowledge and learning, will introduce new ways to detect the students' affective states and to interact with them in different ways (TIMMS, 2016, p. 711). In addition, incorporating AIED into smart classrooms collecting data from the many sensors disposed in such an environment would require large amounts of educational data mining and lead to new models of perceiving student behavior.

AI will reduce costs for learners, compared to the cultivation of experienced teachers, as it is a technology that will duplicate unlimited assistants, teachers, supervisors and mentors, who will influence all aspects of human life. In the near future, education will no longer be limited to classrooms only, and educational modes will be changed in teaching materials and methods - which will take place in four suggested stages by Wang et al. (2018, p. 155-157):

i) Increasing teaching efficiency: in the initial stage of the intelligence era, AI will record the learning results of each student, which will constitute the data analyzed by the assistants, and will serve as a conclusion for teachers. Based on this information (personality, relevant knowledge domain, learning efficiency, etc.), teachers will offer relevant content to each student, resulting in more effective teaching. With the development of technology, an "AI partner" will be available to accompany a student and record their data throughout their lives. Such partner will collect more complete data about a person and reveal more information that is often overlooked in everyday life, better outlining his/her personality. Furthermore, this "AI partner" will help students to understand their acquired knowledge more broadly and precisely - and that understanding obtained by the "partner" may be better than that which any human being would be able to obtain. At this stage, AI will not change the ways and opportunities through which education occurs. Nor will it transform contents, but the high efficiency of teaching will lead to a greater breadth and depth of the content 
learned. This situation will require that universities accelerate the speed of cultivating composite and specialized talent in innovation, who are more aspiring and creative, bringing competitiveness;

ii) Focus on cultivating student talent: time for teaching and learning is limited, but the AI experience can be shared. At the intermediate stage, every AI teacher can share and learn from many experiences to improve teaching and learning, even raising the standard of teachers' wisdom. This will allow them to meet the particular requirements of each student, offering them personalized education, which generates equity throughout the process. During this stage, few changes are made to contents, but education providers will offer AI teachers instead of human ones. As AI teachers offer high quality teaching to students at low cost, the educational focus will shift from "teaching" to "learning". The breadth and depth of knowledge will no longer be limited to "teaching", and thus, the content and objectives of teaching will focus on the cultivation of talents aware of innovation, motivated and ready for learning;

iii) Reversion of content and teaching methods: when advanced, AI will transform its role ceasing to be an external tool to become an organic part. Man and machine will be integrated, making the human capable of learning beyond the current reach. Human/AI interaction will flow as much as, currently, the human obtains information through his/her organs (eyes, ears, etc.). Huge changes will occur in educational methods and content, as the memorization of diverse complicated knowledge will no longer be necessary, since trivial works will be performed only by AI. Knowledge, thus, will be acquired as easily and quickly by human beings as a download of a book, even in great length and depth. The breadth and depth of knowledge of this "super" man will have nothing to do with "teaching" or "learning": at that stage, the "super" man's IQ, EQ, personality and hobby will be identical. What a "super" man will have to do is to learn how to apply and control the AI integrated in him/her, and complete creative, intuitive and perceptual tasks, where AI is less competent than human intelligence. Thus, this knowledge inherent exclusively to human intelligence will be the important part of education at this stage.

iv) Alterations on evaluation methods: evaluations and tests currently continue to focus on the memory of knowledge and methods/routines for solving problems. But AI will reverse this situation, more accurately assessing student performance. The ubiquitous "AI partner" will record a student's entire learning process, pertinently testing his/her knowledge and skills, analyzing failures to formulate a learning plan that compensates them. In this form of learning, every student must clarify what have been learned, what have been mastered and what have been ignored, and semester exams and skills proficiency tests will be eliminated. Standardized content will no longer be evaluated, but open, comprehensive and interdisciplinary content. 
It is clear that the view of the authors above seems to be quite optimistic, but it depends on other technological advances (besides a long time), and on the adaptation of the whole way of life of the human being to occur. Furthermore, even if it does not happen exactly in the way they have proposed, it is clear that this evolutionary line can clarify ways in which education (including legal one) will be proposed in a more or less distant future, as well as launching initial parameters for a criticism and the development of an ethics capable of subsidizing the regulation of this process of future education by the theory of both Pedagogy and Law.

The fast pace of technological innovation and the displacement of associated jobs, widely recognized by experts in the field of AI, implies that higher education requires a reconsideration of the role and pedagogies of teachers. The current use of technological solutions, such as "learning management systems" or IT solutions to detect plagiarism, already raises the question of who sets the teaching and learning agenda - whether companies or higher education institutions. Many sets of tasks currently placed at the center of higher education practice will be replaced by AI based on complex algorithms designed by programmers that can convey their own biases or agendas in operating systems. Continued criticism and research (mainly related to ethics) in the proposed solutions are thus crucial to ensure that universities remain institutions capable of promoting and developing knowledge and wisdom (POPENICI; KERR, 2017, p. 32-33). Thus, universities need to rethink their pedagogical functions and models, as well as their future relationship with AI solutions and their owners. In addition, higher education institutions are facing the vast record of possibilities and challenges opened up by the opportunity to adopt AI in teaching and learning. Such solutions present new openings for education for all, promoting lifelong learning in a strengthened model that can preserve the integrity of fundamental values and the purpose of higher education.

Major advances in AI theory and applications expected in the coming decades mean that the current workforce in all sectors will have to prepare for a possible substitutive effect. For He, Shen and Xin (2020, p. 56), AI will have a strictly negative impact on low-skilled work, but its influence is still undefined on high-skilled work. Adequate AI-related education, however, is able to mitigate negative effects. Thus, they outline an assessment of three basic skills cultivated in AI education - cooperation, communication and manipulation. For undergraduates highly susceptible to the influence of $\mathrm{AI}$ on placement in the job market, more efforts are needed by universities and companies to help them adapting to the future AI work environment. A list of higher education courses (from the Chinese organization of such courses) that need to incorporate computer science teaching is proposed by the authors (HE; SHEN; XIN, 2020, p. 51): 


\begin{tabular}{|c|c|}
\hline Categories & Courses \\
\hline Agriculture & Forestry, Animal Husbandry, Fishing \\
\hline Arts & Music, Drama, Cinema, Design \\
\hline Economic Sciences & Economy, Public Finances, Finances \\
\hline Education & Pedagogy, Physical Education \\
\hline Engineering & Mechanical Engineering, Materials Science, Energy, Electrical Engineering \\
\hline History & History, Archeology \\
\hline Information Engineering & $\begin{array}{l}\text { Automation, Computer Science, Architecture, Environmental Sciences, Mining, } \\
\text { Transports, Aerospace Engineering, Nuclear Science }\end{array}$ \\
\hline Law & Law, Political Science, Sociology, Ethnology \\
\hline Literature & Literature, Journalism \\
\hline Administration Sciences & $\begin{array}{l}\text { Business Management, Public Administration, Operations Research, Electronic } \\
\text { Commerce }\end{array}$ \\
\hline Medical Sciences & Basic Medicine, Clinical Medicine, Public Health, Traditional Medicine \\
\hline Philosophy & Philosophy, Logic, Religious Studies \\
\hline Sciences & $\begin{array}{l}\text { Mathematics, Physics, Chemistry, Astronomy, Geography, Atmospheric Sciences, } \\
\text { Geology, Psychology, Biology }\end{array}$ \\
\hline
\end{tabular}

Source: (HE; SHEN; XIN, 2020, p. 51).

In relation to the professions described above, all of which are highly qualified, none has a susceptibility to automation greater than $50 \%$ in job positions. But, focusing on the most typical professions of Law graduates - Advocacy and Judiciary - the authors present that, according to Chinese reality, about $15.8 \%$ is the degree of susceptibility to automation (HE; SHEN; XIN, 2020, p. 52). It is clear that these data are very specific to the Chinese reality, quite different from the Brazilian one, for example (be it in relation to the political regime, demography, the form of socialization and political organization, the jobs that are actually occupied by graduates in Law beyond the traditional ones, and several other factors). It is also true that in Brazil a large part (perhaps the largest) of Law graduates are placed in Public Administration and Judiciary auxiliary positions, in very different professions. However, these data already serve to illustrate probabilities and encourage research related to other national contexts. Such results, however, demonstrate that (HE; SHEN; XIN, 2020, p. 50): i) interactive communication skills between humans, as well as between humans and machines, should be emphasized in higher education; ii) creativity is a weapon against computing and the substitution effect of AI.

Many traditional instructional methods are based on presenting facts and concepts followed by test questions to students, but AI involves capturing and mastering 
knowledge, providing power of intelligent assessment and feedback, among others (BELE, 2018, p. 24). AI in a specific area makes education highly interactive, accessible and individualized. E-learning is the learning delivered or activated via electronic technology, and it encompasses learning through a variety of technologies (i.e. internet, television, video, intelligent tutoring and computerized training). It can be of great value when used as part of a well-planned and adequately supported education/training environment, but it does not replace or render existing traditional educational theories and approaches obsolete. An intelligent tutoring system (ITS) provides immediate and personalized instructions to students, usually without requiring the intervention of a human teacher, as in online teaching. While it is very difficult to provide a personal training assistant for each student, a virtual training assistant that captures the subjects and teaching experience of experienced coaches can be an interesting route. This kind of system has been adopted by researchers in education, psychology and AI. The ITS can also be classified by the model tracking tutor algorithm. One of the goals of ITS is to adopt hypermedia courses for each user, by controlling the level of learning, the navigation of the course, reviewing the available information, and reviewing the training and its methodology, explaining errors, answering questions, student advice, etc. In other words, ITS allows the student to be taught content, offered an assessment and also for education to be adapted to the student's performance. ITS thus creates a learning environment in which the role of human teachers is largely replaced by the tutor module and the domain knowledge module (BELE, 2018, p. 25). A system plans and teaches individuals, maintaining the belief inn each student module and acting according to the best teaching strategy. ITS can also be classified by the model tracking tutor algorithm.

Educational technology companies (EdTechs) are implementing emotional AI to quantify social and emotional learning, in facial coding methodologies that use algorithms and computer vision to see, recognize, categorize and learn about facial expressions of emotion - and McStay (2019) assesses the nascent use of these technologies in education, demonstrating that there is a clash between public and private interests in the use of such technologies in the face of both the rights of students and the point of view of the effectiveness of the technology. The author's position is that, at a first glance, the use of AI technologies to assist teachers in their activities is not problematic. Furthermore, emotional AI is not seen as being something naturally unethical as well. However, there are several methodological, legal and normative problems with emotional AI technology, especially in relation to applications based on facial coding (MCSTAY, 2019, p. 12). Firstly, effectiveness, validity and representativeness of facial data used for training emotional AI are questionable - that is, it is plausible to raise doubts about the certainty of the results obtained with the 
analysis of the facial data of those submitted to the technology. Furthermore, the quest for the well-being of students (especially if they are children of school age) may not be aligned with a situation in which their facial expressions are stored and evaluated. In other words, mining the students' emotional life could be considered wrong from an ethical point of view, especially when the extraction of values from these procedures does not serve their well-being. Finally, it is problematic to use inferences about learners' emotions to train neural networks deployed for other commercial purposes (such as advertising). In other words, it is very plausible to think about the possibility of deviations in the scope of obtaining the data, since this information obtained in the teaching environment can be used for other socially determining purposes (such as social scoring). As a result, there must be principles of minimizing data collection that should serve to question the extent to which emotional AI is necessary for successful education.

Interdisciplinary research in the learning sciences has been helping to understand the way humans learn, and the result of such research is an improved understanding of the best way to teach and to train people. From now on, this same type of knowledge should better inform the development of AI for use in education. This type of understanding better positions the design of AI algorithms capable of analyzing advanced educational data at high speed, but also, in a more individualized way for students. However, most commercial AI developers know little about learning or teaching. Thus, Luckin and Cukurova (2019, p. 2824) argue that, to ensure that AI technologies in education incorporate the careful analysis and knowledge obtained by the learning sciences, partnerships between teaching stakeholders (developers, AI educators and researchers) should be established.

Partnerships that support co-design among stakeholders provide a method for bringing research and practice worlds together in the learning sciences with those who develop AI for use in education and training. The proliferation of AI development for education adds an even more urgent need for stakeholder approaches, making it necessary to ensure that educators can help AI developers better understand teaching and learning. It should also be ensured that AI developers can support educators and trainers to better understand AI and its application in education. In addition, there is an interdisciplinary partnership between stakeholders that can be used to ensure that AI offers some of the educational benefits that its application promises in other areas. However, caution is also needed with regard to the way in which these partnerships are established, as large technology companies already dominate much of the EdTech scenario - and thus it is essential that they do not monopolize the relationship with educators, which can lead to a very biased and restricted educational AI future. 
Therefore, diversity of brands/companies that supply and develop EdTech, as well as the technologies themselves, is essential. ${ }^{2}$

\subsection{ARTIFICIAL INTELLIGENCE IN LEGAL EDUCATION}

An interesting analogy can be drawn between the importance of introducing AI into Law and the discovery of Justinian's Digest - which revealed the immense and sophisticated corpus of Roman Law to those who lived under customary orders from European kingdoms and regions of the 11th century, influenced the development of Canon Law and, consequently, much of what is currently understood by Law in the West (MAHARG, 2017). But the Digesto presented enormous problems of information overload for students, teachers and professionals: how was all this new knowledge to be interpreted, taught and learned, disseminated, practiced? New forms of legal learning were developed, as well as new and sophisticated forms of academic and professional texts. Students have become qualified readers of such professional forms of legal texts to enter legal learning.

In this sense, a free application called LawBot, a chatbot designed by Cambridge Law students, proposes to advise victims of crimes about their rights. That initiative, together with the idea of students organizing their learning as a public good, goes to the heart of what universities are about, going back to the foundation of the first universities: in Bologna (1080s), students, not monks , administered the university. They developed the new universitas, negotiated their rights and obligations with government officials, disciplined themselves, organized teaching and assessment, hired academics, etc. Students were linked to the university in ways almost inconceivable in the current way.

Law students must have a basic understanding of the current state of AI and its likely short-term impact on Law - which will give them the opportunity to guide their careers to avoid the legal occupations most vulnerable to automation and to focus on activities for which their education and skills are valuable (SURDEN, 2017). In general, the tendency of AI has been the automation of highly structured and repetitive tasks, or with discernible underlying patterns - in machine learning, for example, focused on pattern detection algorithms in large amounts of data to automate various tasks (automated product recommendations, credit card fraud detection, etc.).

\footnotetext{
${ }^{2}$ On the dangers of technocracy and the need to democratize technological development in legal education, see the text by Maharg (2020) Same As It Ever Was? Technocracy, Democracy and the Design of Discipline-Specific Digital Environments.
} 
It is very important that students become aware of this distinction - between lower, repetitive tasks, and higher, creative and human activities - as the current AI is not yet able to replicate higher human cognitive tasks (SURDEN, 2014). Thus, future legal operators will be able to dedicate themselves more to activities that require higherorder cognitive skills (legal analysis, judgment, advice to clients, construction of new legal and political arguments, and complex writing) and not to mechanical, repetitive and routine ones.

When observing the current state of the art, the potential and implications of applying AI to various professional profiles of Law and politics (lawyers, judges, prosecutors, police, forensic scientists, members of public or corporate professional bodies, etc.), it is clear that legal practice has not yet adopted such technologies deeply and comprehensively, but there is a potential for the adoption of tools based on it (NISSAN, 2019, p. 459). Digital tools based on weak AI have been developed to help solving problems faced by lawyers. It is then a matter of Law professionals deciding what to buy. The ordinary citizen remains dependent on human lawyers. Legal systems have not yet been changed by the available AI technology. There are negotiation tools designed to relieve users from incurring litigation costs (such as the Australian Family Law specialist Split Up system) and software self-help kits for writing a valid last will and testament or declaration. Tools to be used by members of the public run risks similar to self-representation in Court when assistance from no attorney is available. For both legal professionals and the police, AI tools can help understanding the context in which they work, but decisions are still made based on unequal power and unequal access to information: money can buy the power of proper legal argument, what puts the poorest at a disadvantage, and the general trend of policies at the global and national level, makes it very likely that this disadvantage will increase. This is not a problem caused by the technology itself, but by the social and political contexts in which the technology is being developed for potential buyers and with economic disincentives for access to members of the general public.

A new type of advanced legal education is needed, recognizing the impact of AI and not clinging to technological neutrality (SJÖBERG, 2019, p. 185-186). Such a legal education must have teachers and students open to learning and understanding the legal implications of algorithms in various digital environments - which leads to yet another area of studies and research: information security, a scarce field of lawyers, despite of confidentiality issues, integrity and availability, which are critical factors for the success of reliable AI.

Furthermore, for jurists, the technological vocabulary of AI is very difficult (i.e. cognitive computing, neural networks, natural language processing, big data repositories, data mining, machine learning, etc.), and about that difficulty, we highlight the dynamic 
AI-based algorithms, which are self-learning and self-modifying during the operation of an already implemented system. In this digital environment, it is very difficult to defend the Rule of Law, for exemple. Despite such difficulty, currently the management of digital resources is part of the legal profession, internally and externally in relation to the legal domain. Balancing interests against substantive rights requires up-to-date education and training in this regard, as well as expanding the methodological approach to include AI-based methods. The academic fields of IT Law and Legal Technology offer a theoretical framework for those types of studies. AI has the potential to improve the management of digital resources, but this requires legal education and a comprehensive analysis of how a legal system is built.

\section{CONCLUDING REMARKS}

Legal education has to be epistemologically redesigned - leaving the "retrospective" model in a dogmatic past (which applied past solutions to present and future problems, with teacher-authorities with all knowledge), and assuming a "prospective/projective" model, with the prioritization of the development of skills for dealing with complex problems and the construction of alternatives that do not exist hitherto.

To this redesigned model, an interdisciplinary perspective must be added, including knowledge that is not traditionally part of the jurist's repertoire. Coding and use of new technologies, in addition to the communicative capacity (working collaboratively) should be the focus of a legal education capable of offering the future professional alternatives and skills to deal with the new technological social reality. The focus on interdisciplinarity must also aim to recent innovations already put into practice, not only in an explanatory way, but also, in a way in which the development of students' creative, prospective and projective skills takes place based on their use and reasoning. Blockchain, AI, smart contracts, databases and quantitative methodologies (among others) must be combined with the training legal typical skills and capabilities (which continue to have their importance in the new digitalized world), so that new solutions are found for new problems.

All those capabilities should serve for the legal operator to perform not only traditional technical work, but, primarily, to provide reliability to new features that are created by and for technologies. Technological disruptions must be understood and systematized according to the critical and constructive reasoning that differentiates Law from other areas of knowledge. Creativity and interdisciplinarity are still (and may remain for a long time) human domains, which, unlike single and repetitive tasks, cannot be exercised by autonomous systems. The new skills and competencies 
demanded by the change in the current scenario, marked by the emergence of a digital economy, do not refer only to undergraduate programs as well. Creativity, interdisciplinarity, collaborative work and a shift to a prospective and projective focus on legal education are skills and knowledge that must also be integrated into LLMs, $\mathrm{PhD}$ and postgraduate programs in general.

There are authors whose studies on the application of AI to education lead to very optimistic conclusions. In those visions, greater efficiency of the teaching and learning processes would be obtained through more detailed knowledge of the students' behavior and emotions, with the use of robotics, deep learning and IoT (among other technologies addressed in an interdisciplinary way), since a more individualized teaching (in relation to the particular needs of each student) could be offered. On the other hand, it is taken for granted by other authors that less qualified professions, with repetitive, mechanical activities, will be replaced by AI. But more qualified professions, dependent on higher education, have an even less defined future. In this sense, there are authors who believe that teaching programming and coding even in courses that traditionally do not involve cutting-edge technology, added to the valorization of human creative and communicative capacities could avoid the clash of the professions corresponding to these formations caused by the substitution effect brought about by the development of AI.

Collection and processing data about students' personality and behavior by AI is not necessarily a bad thing. However, there is a great risk of misuse of such data - that is, what would initially be stored and analyzed for the purpose of personalizing/individualizing curricula and methodologies could be used for other purposes, such as commercial and political. Thus, the development of these technologies (which can of course be of great value when used for the purpose of making the education process more precise and efficient) must be accompanied by deep critical reflections on their means and effects, so that a standardization (which involves the construction of ethical-legal rules and principles, but must go beyond that) befitting its complexity can be built.

It is necessary to ensure that the same interdisciplinary approach that has enabled greater knowledge about human learning continues to be cultivated, in order to be incorporated into educational AI. Thus, partnerships between educators and business that develop educational AI must occur, in order to integrate them more and more into this great enterprise. On the other hand, there is a need for a conscious regulation of the great possibility of monopoly of education technologies involving AI by the companies that develop them - at the risk of incurring a biased and restricted education. 
As a highly qualified area, Law and legal education are not yet under a very pressing possibility of substitution by AI - however, universities must make students aware that there are specific tasks in the legal professions that may be replaced by AI, and advise them to focus their skills and knowledge in areas where this technological form does not have a substitutive effect. Despite the difficulties that interdisciplinary understanding between Law and technology entails, it must be incorporated into legal education programs.

Finally, it is necessary to describe the limitations related to this research. First, it should be noted the concentration of studies related to the use of technologies in education in contexts very different from the Brazilian (such as China, USA and Australia), which implies that the reader should consider the results presented here very sparingly when trying to adapt them to other contexts. And, secondly, although the various sources used here have brought empirical studies and quantitative approaches, there is still a very imaginative, prospective and subjective character of the future of AI in education.

\section{REFERENCES}

ALTWICKER, Tilmann. International Legal Scholarship and the Challenge of Digitalization. Chinese Journal of International Law, v. 18, n. 2, p. 217-246, 2019. DOI: https://doi.org/10.1093/chinesejil/jmz012. Available at: https://academic.oup.com/chinesejil/article-abstract/18/2/217/5510128? redirectedFro $\mathrm{m}=$ fulltext. Accessed in: 18 Nov. 2020.

BECKER, S. A. et al. NMC Horizon Report: 2017 Higher Education Edition. Austin: The New Media Consortium, 2017. Available at: https://www.learntechlib.org/p/174879/. Accessed in: 18 Nov. 2020.

BELE, Sanghesh B. Contribution of Artificial Intelligence to the E-learning. International Research Journal of Innovations in Engineering and Technology (IRJIET), v. 2, n. 5, p. 24-27, 2018.

BENNETT MOSES, Lyria. Helping Future Citizens Navigate an Automated, Datafied World. UNSW Law Research Paper, n. 19-28, 2019. Available at: https://ssrn.com/abstract=3370016. Accessed in: 18 Nov. 2020.

DIAMOND, Randy J. et al. Let's Teach Our Students Legal Technology... But What Should We Include? AALL Spectrum, v. 23, n. 1, p. 23-28, 2018. 
ERSHOVA, Inna V. et al. The Phenomenon of Digitization in Legal Business Education. In: POPKOVA, Elena G. (ed.). Ubiquitous Computing and the Internet of Things: Prerequisites for the Development of ICT. Cham: Springer, 2019. p. 145-152.

FENWICK, Mark; KAAL, Wulf A.; VERMEULEN, Erik P. M. Legal Education in a Digital Age: Why Coding Matters for the Lawyer of the Future. In: COMPAGNUCCI, Marcelo Corrales et al. (ed.). Legal Tech and the New Sharing Economy. Singapore: Springer, 2020. p. 103-122.

FUNDAÇÃO GETÚlIO VARGAS. Exame de ordem em números. 2016. v. 3. Available at: https://fgvprojetos.fgv.br/sites/fgvprojetos.fgv.br/files/oab_3_edicao_v4_ web_espelhado.pdf. Accessed in: 18 Nov. 2020.

GUILHERME, Alex. AI and education: the importance of teacher and student relations. AI \& Society, v. 34, p. 47-54, 2019. DOI: https://doi.org/10.1007/s00146017-0693-8. Available at: https://link.springer.com/article/10.1007\%2Fs00146-0170693-8. Accessed in: 18 Nov. 2020.

HAGAN, Margaret. Design comes to the Law School. In: DENVIR, Catrina (ed.). Modernising Legal Education. Cambridge: Cambridge University Press, 2020. p. 109. 125.

HE, Wenqing; SHEN, Yifan; XIN, Ying. AI Education for Everyone: How to Integrate Future Labor Force into Digital Frontier? In: KOKURYO, Jiro; MARACKE, Catharina; WALSH, Toby Walsh. AI for Everyone: benefitting from and building trust in the technology. [S.l.]: AI Access, 2020. p. 41-56. Available at: http://www.cse.unsw.edu.au/ ${ }^{\sim}$ tw/ai4everyone.pdf. Accessed in: 18 Nov. 2020.

HOOKWAY, Branden. Interface. Cambridge, London: MIT University Press, 2014.

KOEBLER, Jason. Rise of the Robolawyers: how legal representation could come to resemble TurboTax. The Atlantic, Apr. 2017. Available at: https://www.theatlantic.com/magazine/archive/2017/04/rise-of-the-robolawyers/5177 94/. Accessed in: 18 Nov. 2020.

LEGG, Michael. New Skills for New Lawyers: Responding to Technology and Practice Developments (January 1, 2018). The Future of Australian Legal Education (Thomson Reuters 2018); UNSW Law Research No. 18-51. Available at: https://ssrn.com/abstract=3235075. Accessed in: 18 Nov. 2020.

LESKOVA, Yulia G.; SEROVA, Olga A.; LUKYANOVA, Natalia Y. Master's Educational Programs in the Context of the Digital Economy: Main Trends. In: 
POPKOVA, Elena G. (ed.). Ubiquitous Computing and the Internet of Things: prerequisites for the Development of ICT. Cham: Springer, 2019. p. 835-844.

LUCKIN, Rosemary; CUKUROVA, Mutlu. Designing educational technologies in the age of AI: A learning sciences-driven approach. British Journal of Educational Technology, v. 50, n. 6, p. 2824-2838, 2019. DOI: https://doi.org/10.1111/bjet.12861. Available at: https://bera-journals.onlinelibrary.wiley.com/doi/abs/10.1111/bjet.128 61. Accessed in: 18 Nov. 2020.

MAHARG, Paul. Let's get digital: Paul Maharg explores the potential for AI \& legal education. New Law Journal, 2017. Available at: https://www.newlawjournal.co.uk/content/let-s-get-digital-0. Accessed in: 18 Nov. 2020.

MAHARG, Paul. Same As It Ever Was? Technocracy, Democracy and the Design of Discipline-Specific Digital Environments. In: DENVIR, Catrina (ed.). Modernising Legal Education. Cambridge: Cambridge University Press, 2020. p. 147-165.

MCSTAY, Andrew. Emotional AI and EdTech: serving the public good? Learning, Media and Technology, p. 1-14, 2019. DOI: https://doi.org/10.1080/17439884.2020.1686016. Available at: https://www.tandfonline.com/doi/full/10.1080/17439884.2020.1686016. Accessed in: 18 Nov. 2020.

MIRONOVA, Svetlana; BOGDANOVA, Tamara; SIMONOVA, Svetlana. The introduction of digital technologies in the educational process of training lawyers. SHS Web of Conferences, v. 69, n. 79, p. 1-6, 2019. DOI: https://doi.org/10.1051/shsconf/20196900079. Available at: https://link.springer.com/article/10.1007\%2Fs00146-015-0596-5. Accessed in: 18 Nov. 2020.

NISSAN, Ephraim. Digital technologies and artificial intelligence's present and foreseeable impact on lawyering, judging, policing and law enforcement. AI \& Society, v. 32, p. 441-464, 2017. DOI: https://doi.org/10.1007/s00146-015-0596-5. Available at: https://link.springer.com/article/10.1007\%2Fs00146-015-0596-5. Accessed in: 18 Nov. 2020.

POPENICI, Stefan A. D. ; KERR, Sharon. Exploring the impact of artificial intelligence on teaching and learning in higher education. Research and Practice in Technology Enhanced Learning, v. 12, n. 1, p. 22-35, 2017. DOI: https://doi.org/10.1186/s41039017-0062-8. Available at: https://telrp.springeropen.com/articles/10.1186/s41039-0170062-8. Accessed in: 18 Nov. 2020. 
SJÖBERG, Cecilia Magnusson. Legal Automation: AI and Law Revisited. In: CORRALES, Marcelo; FENWICK, Mark; HAAPIO, Helena (eds.). Legal Tech, Smart Contracts and Blockchain. Cingapura: Springer, 2019. p. 173-187. DOI: https://doi.org/10.1007/978-981-13-6086-2_7. Available at: https://link.springer.com/chapter/10.1007\%2F978-981-13-6086-2_7. Accessed in: 18 Nov. 2020.

SUBRAHMANYAM, V. V.; SWATHI, K. Artificial Intelligence and its Implications in Education. International Conference Improving Access to Distance Higher Education Focus Underserved Communities Uncovered Reg. Kakatiya University, p. 1-11, 2018. Available

https://www.researchgate.net/profile/Vv_Subrahmanyam/publication/328686410_Art ificial_Intelligence_and_its_Implications_in_Education/links/5bdbe824a6fdcc3a8db78 f8e/Artificial-Intelligence-and-its-Implications-in-Education.pdf. Accessed in: 18 Nov. 2020.

SURDEN, Harry. Machine Learning and Law. Washington Law Review, v. 89, p. 87$115,2014$.

SURDEN, Harry. What to Teach Law Students About Artificial Intelligence and Law? Northwestern Law Review Online (Bridges II), 2017. Available at: https://ssrn.com/abstract=3120123. Accessed in: 18 Nov. 2020.

THE LAW SOCIETY OF NEW SOUTH WALES. Commission of Inquiry. The Future of Law and Innovation in the Profession (FLIP) Report. Sydney: The Law Society of New South Wales, 2017. Available at: https://www.lawsociety.com.au/sites/default/files/2018-03/1272952.pdf. Accessed in: 18 Nov. 2020.

THOMSON, David I. C. Online Learning and the Future of Legal Education. University of Denver Legal Studies Research Paper, n. 20-01, p. 1-26, 2020. Available at: https://ssrn.com/abstract=3515416. Accessed in: 18 Nov. 2020.

TIMMS, Michael J. Letting Artificial Intelligence in Education Out of the Box: Educational Cobots and Smart Classrooms. International Journal of Artificial Intelligence and Education, v. 26, p. 701-712, 2016. DOI: https://doi.org/10.1007/s40593-016-0095-y. Available at: https://link.springer.com/article/10.1007/s40593-016-0095-y. Accessed in: 18 Nov. 2020.

VOCHOZKA, Marek (eds.). Digital Transformation of the Economy: Challenges, Trends and New Opportunities. Cham: Springer, 2020. p. 455-462. 
WANG, Bin et al. Artificial Intelligence and Education. In: JIN, Donghan (ed.). Reconstructing Our Orders. Singapore: Springer, 2018. p. 129-161.

WEBB, Julian. Information technology and the future of legal education: a provocation. Griffith Journal of Law \& Human Dignity, v. 6, n. 3, p. 72-104, 2019. Available at: https://griffithlawjournal.org/index.php/gjlhd/article/view/1085. Accessed in: 18 Nov. 2020.

YAVORSKIY, M. A.; MILOVA, I. E.; BOLGOVA, V. V. Legal Education in Conditions of Digital Economy Development: Modern Challenges. In: ASHMARINA, Svetlana; MESQUITA, Anabela. The Sundarbans: A Disaster-Prone Eco-Region. [S.l.: s.n.], 2020.

ZHAO, Yingfang; LIU, Guibao. How Do Teachers Face Educational Changes in Artificial Intelligence Era. Advances in Social Science, Education and Humanities Research (ASSEHR), v. 300, p. 47-50, 2018. DOI: https://doi.org/10.2991/erss18.2019.9. Available at: https://www.atlantis-press.com/proceedings/erss-18/55912681. Accessed in: 18 Nov. 2020.

Como citar este documento:

FORNASIER, Mateus de Oliveira. Legal education in the 21st century and the artificial intelligence. Revista Opinião Jurídica, Fortaleza, v. 19, n. 31, p. 1-32, maio/ago. 2021. 